\title{
Blended learning and the language teacher: a literature review
}

\section{Aprendizaje mixto y el profesor del lengua extranjera: una revisión de la literatura}

\author{
Jenny Alexandra Mendieta Aguilar \\ Department of Foreign Languages and Cultures \\ Universidad de La Sabana \\ Chia, Colombia \\ E-mail: jenny.mendieta@unisabana.edu.co
}

Received: 20 - Jun - 12 / Accepted: 8 - Oct -12

\begin{abstract}
An innovative idea which is increasingly gaining attention is the infusion of technology into face-to-face language curricular programs. Nonetheless, although "the approach of blending Computer-assisted Language Learning (CALL) applications with face-to-face teaching and learning is as old as CALL itself' (Neumeier, 2005, p. 163), CALL as a field still lacks qualitative research on blended learning. There is insufficient information about teachers' perceptions and the roles they play in these mixed environments, and without an understanding of these features, it is difficult to create new and effective models (Grgurovic, 2010). Research has been conducted comparing learning outcomes in traditional and blended foreign language classes, yet the various sociocultural (external) and psychological (internal) aspects that mediate teachers' and learners' transition from face-to-face to online learning, seem to go unexamined (White, 2006). Throughout this paper, therefore, I review literature on the infusion of technology into the curriculum, specifically in relation to blended learning, so as to a) illustrate teachers' views about blended leaning and their transition from face-to-face to blended/online instruction; and b) discuss ways in which future research might provide an alternative understanding of how language teachers manage the new-work order established by the online learning component present in blended programs.
\end{abstract}

Key words: the infusion of technology into the curriculum, blended learning, online learning, language teaching and learning, teachers' roles and views towards blended learning.

\section{Resumen}

Una idea innovadora que está ganando cada vez más atención es la infusión de la tecnología en los programas curriculares de idiomas cara a cara. Sin embargo, a pesar de que las aplicaciones del "enfoque combinado del Aprendizaje de Idiomas asistidos por Computador (CALL) con enseñanza cara a cara y el aprendizaje es tan antiguo como la propia CALL". (Neumeier, 2005, p. 163), CALL como un campo todavía carece de una investigación cualitativa sobre aprendizaje combinado. No hay suficiente información sobre las percepciones de los profesores y de los papeles que desempeñan en estos entornos mixtos, y sin una comprensión de estas características, es difícil crear modelos nuevos y efectivos. (Grgurovic, 2010). La investigación se ha llevado a cabo comparando los resultados del aprendizaje en clases de lenguaje extranjero combinados y tradicionales, sin embargo, los diversos aspectos socioculturales (externos) y psicológicos (internos) que median la transición de los profesores y alumnos del aprendizaje en línea cara a cara, parecen ir sin examinar (White, 2006). A lo largo de este papel, por lo tanto, yo reviso la literatura en la infusión de la tecnología dentro del currículo, específicamente en la relación del aprendizaje combinado, con el fin de a) ilustrar las opiniones de los profesores acerca del aprendizaje combinado y su transición de la instrucción cara a cara a la instrucción combinada/en línea; y b) discutir la manera en que las investigaciones futuras podrían proporcionar una comprensión alternativa de como los profesores de idiomas gestionan la nueva orden de trabajo establecida por el componente del aprendizaje en línea presente en los programas combinados. 
Palabras clave: la infusión de la tecnología dentro del currículo, aprendizaje combinado, aprendizaje en línea, enseñanza y aprendizaje, roles del docente y opiniones hacia el aprendizaje combinado.

\section{Résumé}

Une idée innovatrice qui attire de plus en plus l'attention est l'inclusion de la technologie dans les plans d'études de langues face à face. Néanmoins, bien que les applications de l'approche combiné de l'apprentissage de langues assisté par ordinateur (en anglais CALL) (combiné) avec l'enseignement face à face et l'apprentissage est aussi ancien que le propre CALL (Neumeier, 2005, p. 163), le CALL comme domaine n'a pas encore une recherche qualitative sur l'apprentissage combiné. II n'y a pas assez d'information sur les perceptions des formateurs et leurs rôles dans ces milieux mixtes et sans une compréhension de ces caractéristiques il est difficile de créer des modèles nouveaux et effectifs. (Grgurovic, 2010). La recherche a été effectuée au moyen de la comparaison des résultats de l'apprentissage dans des cours de langue étrangère combinés et traditionnels. Néanmoins, les divers aspects socioculturels (extérieurs) et psychologiques (intérieurs) qui interviennent dans le passage des formateurs et des étudiants de l'apprentissage en ligne face à face ne semblent être examinés (White, 2006). Dans ce travail, je fais une révision de la littérature sur l'inclusion de la technologie dans le plan d'études, notamment concernant l'apprentissage combiné, afin de : a) illustrer les avis des formateurs sur l'apprentissage combiné et leur passage de la formation face à face à la formation combinée/en ligne ; et b) discuter la manière dans laquelle des recherches futures pourraient-elles donner une compréhension alternative sur la façon dans laquelle les enseignants de langues gèrent la nouvelle consigne de travail établie par le composant de l'apprentissage en ligne présent dans les plans d'études combinés.

Mots clés: l'inclusion de la technologie dans le plan d'études, apprentissage combiné, apprentissage en ligne, enseignement et apprentissage, les rôles du formateur et des avis sur l'apprentissage combiné.

\section{Resumo}

Uma ideia inovadora que está ganhando cada vez mais atenção é a infusão da tecnologia nos programas curriculares de idiomas cara a cara. Entretanto, apesar de que as aplicações do "enfoque combinado da Aprendizagem de Idiomas assistidos por Computador (CALL) com ensino cara a cara e a aprendizagem é tão antiga como a própria CALL". (Neumeier, 2005, p. 163), CALL como um campo ainda carece de uma pesquisa qualitativa sobre aprendizagem combinada. Não há suficiente informação sobre as percepções dos professores e dos papéis que desempenham nestes entornos mistos, e sem uma compreensão destas características, é difícil criar modelos novos e efetivos. (Grgurovic, 2010). A pesquisa foi realizada comparando os resultados da aprendizagem em aula de linguagem estrangeira combinadas e tradicionais, entretanto, os diversos aspectos socioculturais (externos) e psicológicos (internos) que mediam a transição dos professores e alunos da aprendizagem em linha cara a cara, parecem ir sem examinar (White, 2006). Ao longo deste papel, portanto, eu reviso a literatura na infusão da tecnologia dentro do currículo, especificamente na relação da aprendizagem combinada, com o fim de a) ilustrar as opiniões dos professores sobre a aprendizagem combinado e sua transição da instrução cara a cara à instrução combinada/em linha; e b) discutir a maneira em que as pesquisas futuras poderiam proporcionar uma compreensão alternativa de como os professores de idiomas administram a nova ordem de trabalho estabelecida pelo componente da aprendizagem em linha presente nos programas combinados.

Palavras chave: a infusão da tecnologia dentro do currículo, aprendizagem combinada, aprendizagem em linha, ensino e aprendizagem, papéis do docente e opiniões em relação à aprendizagem combinada. 


\section{Introduction}

Education systems change in order to respond to the social, political and economic challenges that societies normally experience (Kelly, 2009). This naturally changing force, together with an increasingly globalized world, translates into the need for stakeholders to continually assess and/or validate what counts as effective learning and teaching, a process which ultimately results in the planning and implementation of national curriculum reforms as well as locally planned pedagogical innovations.

From the different innovative ideas educational organizations currently deal with, one that is increasingly gaining more attention is the infusion of technology into the curriculum. "Over the last 2 decades, educational improvement efforts have placed increased emphasis on curriculum standards and on having the multiple parts of the education system reinforce each other as part of an aligned system. An outgrowth of this trend has been a renewed interest in linking technology and curriculum" (Smith E O'Day, 1990, as cited in Means 2008, p. 14). In consequence, the use of Information Communication Technologies (ICTs) has started to permeate curriculum programs worldwide.

In the field of language teaching, the use of technology has engendered multiple teaching and learning practices that have played out differently at the elementary, secondary, and tertiary educational levels. In the context of tertiary education, for instance, there has been a particular exploration of the role of online learning due to the need to address challenges such as geographic distance, flexibility, but most importantly, as stated by Bach, Haynes and Smith (2006), the need of delivering more higher education to the global population. Blended learning, a model that combines face-to-face and online learning, has thus become one of the strategies adopted by some EFL/ESL university departments to meet the demands of both language learners and local and national educational authorities. And research based on different theoretical and methodological grounds has been conducted in order to uncover its benefits and shortcomings.

Nonetheless, though studies conducted by language and technology experts have illustrated the complex nature of the implementation of such technology-mediated innovations, to date; there has been no systematic analysis of language teachers' roles, perceptions and practices in blended learning and online learning models. As Shelley, White, Baumann and Murphy (2006) note:

\begin{abstract}
The emergence of a host of new ways of organizing language learning over the past two decades (distributed learning, blended learning, hybrid learning, and online learning) has not been met with a similar development of enquiry into what is actually required to carry out teaching roles in such contexts. (p.2)
\end{abstract}

As suggested by educational researchers, it is deemed necessary to place teachers at the heart of educational research in that the decisions they make about what, how and why to teach not only produce change but also confirm or resist existing practices of the wider society (Lo Bianco, 2010; Ricento \& Hornberger, 1996). As noted by White et al. (1991, cited in Lamie, 2005), the fact that teachers can be enthusiastic, resistant or indifferent to curriculum proposals makes it important to take into account their understandings and attitudes, given that "they can destabilize even the most praiseworthy attempts at curriculum development" (p.30). Accordingly, research examining the various personal and external aspects that affect teachers' adoption of technology-mediated ideas is required.

Unfortunately, as stated by White (2006), research on blended learning has been conducted 
to compare learning outcomes in traditional and blended foreign language classes, yet the various sociocultural (external) and psychological (internal) aspects that mediate teachers' as well as learners' transition from face-to-face to online learning, and which provide a richer understanding of this phenomenon, seem to go unexamined. There is also insufficient information about teachers' perceptions and the roles they play in these mixed environments, and without an understanding of these features, it is difficult to create new and effective blended models (Grgurovic, 2010).

Although "the approach of blending Computer-assisted Language Learning (CALL) applications with face-to-face teaching and learning is as old as CALL itself" (Neumeier, 2005, p. 163), CALL as a field still lacks qualitative research on blended learning. Research on CALL has delved into areas related to Tutorial CALL, Social Computing CALL and, more recently, gaming (Blake, 2008). Tutorial CALL, associated with grammar exercises of the mechanical type, has engendered studies related to L2 lexical acquisition and pronunciation. And now with the emergence of intelligent CALL (iCALL), systems which aim to anticipate students' mistakes and offer helpful suggestions, studies examine the role of feedback and individualized instruction. Research on Social Computing CALL, from interactionist and sociocultural perspectives, deals with processes of meaning negotiation and scaffolding, among others. And studies on gaming analyze concepts like agency and the exploration of new identities. Nonetheless, as contended by Neumeier, despite most language learners experience CALL within a BL environment, Blended learning "has hardly ever been the focus of scientific investigation" (p.164).

The following pages therefore attempt to support White's, Grgurovic's and Neumeier's concerns by discussing both what has been examined in research studies on blended language learning and what is still to be addressed. Throughout this paper, I make a review of the literature on the incorporation of technology into the curriculum, specifically in relation to the implementation of blended programs. I do so, however, from the perspective of the teacher. Teachers' perceptions, roles, and practices as well as the external aspects that influence how they respond to the changes motivated by online instruction, as will be evidenced below, should be carefully examined by researchers and curriculum leaders so as to better prepare for the execution of both blended and online programs. It should be noted that for the purpose of this review, several references to ICT and online learning will be included to frame the general discussion since, as observed by Compton (2009), very little has been published specifically on blended language learning and the language teacher. This review therefore addresses the scarcity of resources in the mentioned area by drawing on research and theory from related educational scenarios such as the mainstream classroom.

This overview will be initiated with a discussion around the origins of blended learning in higher education contexts and what blended learning implies in terms of theory (definitions) and design. Afterwards, I will revisit some of the studies that have examined the impact of blended language courses as well as teachers' views about blended learning. Findings reported in these studies will then be analyzed in light of theories about online learning and research on ICT that has taken place in the mainstream classroom. This in order to: a) discuss what lies behind teachers' transition from face-to-face to blended/online instruction; and b) point out some of the ways in which future research might provide an alternative understanding of how language teachers come to grips with the new-work order established by the online learning component that is present in most blended programs. 


\section{Blended Learning: Origins, Definitions, and Design}

Blended learning in higher education. As mentioned earlier, blended learning (BL), which is defined as a combination of face-to-face (F2F) and online learning, is a model that is increasingly being used in higher education institutions in response to some of the social, economic and pedagogical challenges that they are currently facing. Bach, Haynes and Smith (2006) argue that the arrival of online learning (which is part of blended learning) is the result of the modern transformation of higher education alongside other aspects such as globalization and the expansion of higher education in many countries. An increase in the demand implies that "there is a reduction of input costs and resources in relation to the number of output graduates" (Bach, Haynes E Smith, 2006, p.10). To cope with this demand, as the authors suggest, institutions have to use a variety of policies and funding mechanisms, such as providing less classroom teaching input and making use of technology to link classroom activity with self-directed study.

Technology plays a key role here since it can help institutions ensure that programs continue to be of higher quality even in the absence of faceto-face instruction. Additionally, as claimed by Fullan (1997), curricula that rely on the capacity of ICT to transform society can provide a more qualified and accessible means of delivering education, as it "offers opportunities to construct actively networked learning communities that grow consistently in response to the demands of a global need" (p. 5). Consequently, blended learning, a model aimed at effectively using and combining Computer-Mediated Communication (CMC) and web-mediated tools with face-to-face instruction, is also being implemented in language programs in tertiary institutions to both enhance language learning/teaching processes and meet some of the needs facing higher education today (Grgurovic, 2010).

As Jonassen, Howland, Moore \& Marra (2003) contend, it is clear that to be competitive in the global market, there is a growing pressure for university students to not only learn English, but also develop the technological skills that allow them to be successful on the world stage. The challenge, however, as in any other education sector, is "to make sure that the focus on technology does not distract from the focus on knowledge, knowledge creation, its evolution and application" (Bach, Haynes \& Smith, 2006, p.16). As argued by Laurillard, "a university is defined by the quality of its academic conversations, not by the technologies that service them" (2002, cited in Motteram, 2006, p.19).

\section{Defining Blended Learning}

Blended Learning is not new, and contrary to what some may think, it has been in use for more than 20 years. It was first used in the corporate world as a strategy to allow employees to continue in the workplace and study at the same time (Sharma, 2010), but it also emerged in the educational context as a result of: a) the accessibility of computer technology in and outside the classroom, b) the expansion of the pedagogical potential of ICT for teaching and learning (Hong \& Samimy, 2010), and c) the disillusionment generated in online learning with the stand-alone adoption of online media (McDonald, 2008).

Owing to the problems faced with fully virtual environments (e.g. sense of isolation and low motivation), many people started to reject the "either or view of learning online versus faceto-face" (McDonald, 2008, p.3), and instead, resorted to the creation of blended spaces so as to generate more satisfactory outcomes. As Laurillard (2002) points out, a balance of 
media is fundamental to make learning and teaching effective, as "the information and communications technology (ICT) element is unlikely to contribute to more than 50 per cent of the total strategy" (p.3).

The concept of blended learning has been addressed by many authors and it has a varied range of meanings. Tayebinik and Puteh (2012) make a comprehensive review of some of the definitions attached to BL. They present those definitions that are more general and conservative as well as those that are more specific and technology-related. According to Tayebinik and Puteh (2012), Driscoll (2002) provides the broadest definition of all authors since she defines blended learning as a combination of instructional methods or pedagogical approaches. Authors like Gülbahar and Madran (2009), Rovai and Jordan (2004), Thorne (2003), and Yildirim (2007), however, define blended learning as a mixture of online learning or web-based training with face-to-face communication and more traditional methods of learning and teaching.

Neumeier (2005) defines BL as a combination of face-to-face (FF) and computer assisted learning (CAL) in a single teaching and learning environment. And Sharma and Barrett (2007) generalize their understanding of blended learning as a course which combines face-to-face classroom component with an appropriate use of technology:

The term technology covers a wide range of recent technologies, such as the Internet, CD-ROMs and interactive whiteboards. It also includes the use of computers as a means of communication, with applications such as chat and e-mail, and a number of environments which enable teachers to enrich their courses, such as VLEs (virtual learning environments), blogs and wikis. (p. 7)

To Sharma and Barrett, the term blended learning is applicable to a variety of teaching and learning situations and implies a broad range of combinations with regard to face-toface and computer-mediated teaching and learning. According to Sharma (2010), BL has attracted different definitions and stances. The term blend has been used to refer to the mix of teaching modes (CAL and F2F), but also to the combination of technologies (email, phone, web, etc), methodologies (presentation-practiceproduction, TBLT, etc), and probably in the future, real and virtual worlds (e.g. Second Life).

In a similar vein, Lim, Morris and Kupritz (2007) state that among the many definitions available, three representative definitions include:

(a) a learning method with more than one delivery mode being used to optimize learning outcomes and to reduce cost associated with program delivery, (b) any mix of instructor-led training methods with technology-based learning, and (c) the mix of traditional and interactiverich forms of classroom training with any of the innovative technologies (p.28).

Singh and Reed (2001, cited in Lim, Morris E Kupritz, 2007) propose six combinations of blended instruction: (a) offline and online learning, (b) self-paced, live, and collaborative learning, (c) structured and unstructured learning, (d) custom content with off-the-shelf content, (e) work and learning, and (f) blending synchronous physical formats, synchronous online formats, and self-paced, asynchronous formats (p. 28).

Nonetheless Neumeier (2005) notes that despite blended learning (BL) being defined as the mix of CAL and F2F teaching, the distinction between these two models is no longer clear, as classrooms are now equipped with advanced mobile technology; that is, to talk about face-toface instruction does not necessarily imply an absence of the use of technology. As Crook (1994, cited in Neumeier, 2005) states: "It becomes obvious that this distinction becomes increasingly 
blurred as we interact with, around, at, in relation to and through computers" (p.165). Authors like Claypole (2010, cited in Sharma, 2010) argue that there is nothing new about blended learning and that it is namely a response to the logical development of prior pedagogical tendencies involving the mixing of methods of teaching. And according to Westbrook (2008), in the future the term may even disappear or become redundant due to the number of definitions that have been attached to it.

Yet, although some authors contend that there might nothing new about BL, institutions that use blended approaches, as Neumeier (2005) observes, base their practices on the idea that both face-to-face interaction and online methods have inherent advantages, and therefore are beneficial for teachers and learners. According to Tayebinik and Puteh (2012), in agreement with Oh and Park (2009) and Davis and Fill (2007), blended instruction offers teachers the possibility to spend more time with learners in both small groups and individually, and to create a flexible and active learning environment that has the potential to change students' experiences and outcomes. Reasons for using blended instruction include: "improved pedagogy, easy access to knowledge, more interaction among learners, personal presence, cost effectiveness, and ease of revision of learning content" (Tayebinik $\mathcal{E}$ Puteh, 2012, p. 28).

The most important aim of a BL design is thus to create a learning environment that combines the best of both models and that works as a whole and to find "the most effective and efficient combination of the two modes of learning for the individual learning subjects, contexts and objectives" (Neumeier, 2005.p. 165). BL seeks to generate a coherent and harmonious balance between online access to knowledge and face-to-face human interaction by taking into account learners' and teachers' aptitudes and attitudes. BL therefore remains an important concept in language teaching as "its overall focus is concerned with the attempt to identify the optimum mix of course delivery in order to provide the most effective language learning experience" (Sharma, 2010, p. 457).

In this task of creating a balanced blended learning environment it is crucial to consider the various uses of online media so as to be able to distinguish BL from the ICT use that commonly takes place in the classroom. According to Harasim (2000, cited in McDonald, 2008), online media can be used in adjunct or in mixed modes. In the former, technology is used to enhance traditional face-to-face instruction, while in the latter, a significant portion of the curriculum is developed online. Part of the content, skills and strategies that were previously delivered in the classroom are now designed and studied in a virtual environment, one of the reasons why discussions on BL are tightly connected to issues of design.

Blended learning design. Despite the benefits that blended learning offers, it must address challenges related to course design. Tackling the question of design is one of the most salient and difficult, as a "threat of an out-of-balance, discordant blend ... [could] frustrate both student and teacher" (Osguthorpe E Graham, 2003, p.229). According to these authors, to find the right mix between F2F and online modes, designers, curriculum leaders and teachers must address various pedagogical and logistical questions, such as: how often students and teacher meet face-to-face versus how often they will complete assignments online, what will be accomplished during these face-to face meetings versus during the online experiences, how often students and their teacher will interact in the virtual environment, what the purpose of such interaction will be, and how community will be built during both types of contact. Educators 
must also assure they provide pedagogical richness, access to knowledge that goes beyond the information given in textbooks, social interaction, and opportunities for personal agency (self-directed learning).

These different design and pedagogicalrelated issues have generated the creation of a variety of approaches to the planning and evaluation of blended formats in both educational and non-educational contexts. Two of these models will be discussed in this paper. Neumeier (2005), for instance, establishes a set of parameters for blended designs aimed at helping teachers and researchers face as well as assess this complex pedagogical experience. The author describes two stages or processes: focus on mode (selection of lead mode) and model of integration. In the former, one of the modes (F2F or online) is chosen so as to guide the learning process and the structure of the course. This choice has to be made after a careful evaluation of the learning aims, the learners and the available infrastructural resources. In the model of integration, the distribution of learning content and objectives is made, the tasks pertaining to both modes are arranged and sequenced, and the optional or obligatory use of each of these tasks is determined.

Picciano (2009) proposes a somewhat different model. He presents "Blending with Purpose: The Multimodal Model" in recognition of the fact that learners represent different generations, different personality types and different learning styles. The author suggests that teachers and instructional designers try to use multiple approaches to meet the needs of this wide spectrum of students. His model presents five basic pedagogical objectives and activities: a) to use of multiple technologies and media for the delivery of content, b) to incorporate dialectic/ questioning (the Socratic Method) to probe what students know and to refine their knowledge, c) to incorporate reflection (as the ability to share one's reflection with others is beneficial for both learners and teachers), d) to implement collaborative learning, and e) to synthesize, evaluate and assess learning. According to Picciano, the model posits that there is a major benefit of multiple modalities as "they allow students to experience learning in ways in which they are most comfortable while also challenging them to experience and learn in other ways as well" (p.16).

In light of the different issues involved in blended learning, researchers have decided to examine the experiences that are generated in the implementation of such courses. In the specific field of language teaching, as Grgurovic (2011) contends, empirical studies that investigate the use of blended models with language learners are divided into comparison and non-comparison studies. Comparison studies examine the effectiveness of blended learning by comparing blended instruction (face-to-face together with CALL instruction) with traditional instruction (face-to-face without CALL instruction). Noncomparison studies examine blended learning program design and implementation, and student and teacher attitudes towards blended learning (Grgurovic 2011, p. 102).

In the subsequent section of this paper, I will revisit both comparison and non-comparison studies, in special those that examine or provide information about teachers' roles, practices, and views towards $\mathrm{BL}$ programs.

\section{Blended Learning: Voices From the Language Classroom.}

Depending on contextual and the theoretical and methodological consideration that guide their design, studies that delve into blended learning an the role and attitudes of teachers very considerably in therms of results and conclusions. In this review, I revisit five comparison studies (Murday, Ushida E Chenoweth, 2006, 2008) 
and non-comparison (Bañados, 2006; Bijeikien , Rašinskien E Zutkien, 2011; Comas-Quinn, 2011 and Hong and Samimy, 2010) which explore the advantages and challenges of blended programs from different perspectives. However, I focus particularly on those areas identified as causes or conditions for teachers to effectively implement (or not) the online component that has been integrated into the blended curriculum.

Murday, Ushida and Chenoweth (2006, 2008) report the assessment results of a blended language (French) project at Carnegie Mellon University. The authors compared the effectiveness of the implemented blended learning format with that of traditional or conventional courses by examining students' learning outcomes as well as the level of satisfaction reported by instructors and learners through course evaluations, interviews, and focus groups. Although the results suggest that the blended courses were successful and had an increasing level of satisfaction over time, there was not a significant statically difference between the scores learners obtained in the two courses; that is to say, students' learning in both contexts was similar.

As to feedback or levels of satisfaction, the authors reported both favorable and less favorable results. Students commented that they appreciated the ability to work at their own pace, to listen to target language sound clips repeatedly and to access translations when needed. Some of them stated they enjoyed the more casual nature of the interaction that took place during chat sessions. However, they also reported difficulties in making the transition from F2F to online learning. The virtual or online component of the blended program caused some difficulties for learners as they had to switch from the traditional textbook to electronic hypertext, be disciplined and effective self-directed learners, and deal with various technological issues. For teachers, recurring themes included the need for training, control of course materials, and a lack of connection with their students.

From the instructors' perspective, the most critical aspect of teaching a blended language course was training, since the very technology that made the online classes possible complicated their lives when there were technical problems. According to Murday, Ushida and Chenoweth (2006, 2008), a strong sense of community developed as teachers realized that managing the online component of the blended course was quite different from managing the traditional faceto face session. Even so, despite the difficulties, the authors evaluated the blended program as a positive experience in that the benefits in terms of learning and satisfaction outweighed the problems encountered during implementation.

Similar projects like the above have also been implemented in other countries. Bañados (2006), for instance, explores the impact of the implementation of a pilot an ESL blended program at a university in Chile. The study addresses the impact of the program on the learners' linguistic competence and their level of satisfaction. Data, gathered through initial and end of term tests and surveys conducted with 39 students, suggest that students' oral competence improved significantly and that there was also notable progress in all the other skills. Students also favorably evaluated the language learning experiences they had on the course.

Regarding teachers' roles, the author contends that being teachers and online tutors introduced beneficial qualitative changes in teachers' roles as they became guides and collaborators who supported students' learning process, but it also meant a quantitative increase in the number of hours dedicated to learners. "Teachers spend only 1.5 hours a week in faceto-face classes, but they spend a larger number of hours managing learners' work in the online 
environment" (p. 541). They also had to manage the language learning environment to create favorable conditions for language acquisition, which implied helping learners "develop learning strategies and become autonomous and confident learners able to manage a language learning system which relies strongly on their ability to work independently" (p.541). Despite the evident change in participant roles, Bañados (2006), like Murday, Ushida and Chenoweth (2006, 2008), maintains that the results of the study support the success of the blended learning model implemented as language learning was significantly enhanced.

Comas-Quinn (2011), unlike most researchers examining blended learning, evaluated the impact of the introduction of a distance Spanish language learning course at the Open University (UK) from the perspective of the teachers rather than from that of language learning performance. Interviews, class observations, a survey and an institutional report constituted the quantitative and qualitative data gathered for the study. Findings suggest that for teachers in the study online tools were unsuccessfully integrated with the language course and assessment. Teachers considered tools such as tutor group forums and blogs either not useful or unnecessary. Some of them even felt the online experience had simply increased their workload.

According to Comas-Quinn, the success of any model lies especially in the hands of teachers, and in the case of BL, on how well they can make the transition from their role in the face-to-face classroom to the complex roles that online learning demands: "The success of any innovation in education, such as the introduction of online teaching and online technologies (what is commonly referred to as e-learning), is in great part due to how well teachers deal with the new ideas and implement them with their learners" (p.219). Teachers' understanding and use of ICT modes greatly impact students' acceptance of online learning as well as their perceptions of how useful online tools are.

In the same way, teachers' willingness to change is powerfully influenced by learners' expectations as well as by traditional ideas shared by colleagues and students about "what language learning is and what their respective roles in the process are" (p.228). They are equally influenced by their own individual dispositions (beliefs and values) and other internal and external motivators. Some of the current professional development programs, however, do not bear in mind theses various influences, making change less likely to happen.

A transmission of knowledge approach to training fails to acknowledge and properly support the transformation of teachers' identity that results from moving from traditional classroombased teaching to online teaching. The shift goes beyond the acquisition of ICT skills and requires a pedagogical understanding of the affordances of the new medium and an acceptance by the teacher of his or her new role and identity. (p.218)

Hong and Samimy (2010), like ComasQuinn, explored the role of teachers in the successful implementation of BL, but they did it from a different angle; data were gathered from students rather than from teachers. They particularly examined the relationship between teachers' use of Computer Assisted Language Learning modes and language learners' reactions to BL. A booklet questionnaire was distributed to 255 students and questions addressed students' attitudes towards their use and their teachers' use of CALL modes, as well as other issues related to demographics, time devoted to the use of the web, and previous blended learning experiences.

Results confirmed that students who were taught by teachers who actively used CALL modes exhibited more positive attitudes toward 
the online component in BL than those students taught by teachers who incorporated CALL tools to a lesser extent. Thus, as Comas-Quinn noted, teachers' attitudes and uses of technology certainly have an impact on students' acceptance of online learning and their attitudes towards the use of certain tools. According to Hong and Samimy (2010), factors like higher literacy computer skills and experience with a blended environment were not as influential in students' positive attitudes as it was teachers' active use of CALL modes.

I finally refer to Bijeikien, Rašinskien and Zutkien 's (2011) study. These authors examined language teachers' experience in CALL as well as their practices and attitudes towards the blended learning courses created at the Centre of Foreign Languages at Vytautas Magnus University. The research was carried out with 24 teachers of English through qualitative methods such as informal interviews and a questionnaire. In the study, the teaching and learning process was enhanced through resources and activities designed and accessible in a computerized language learning laboratory and in a virtual Moodle environment (p.123). The courses include $20 \%$ or more of instructions offered to the students in the virtual Moodle environment and several classes delivered in the computerized Lab.

Findings revealed both positive comments and criticism. The convenience of access, the learner-centered approach and the communicative practice that the blended courses generated were valued positively by teachers as learners were able to work consistently and independently. Nevertheless, the lack of face-toface contact was reported as the most negative factor, as there were students who always needed more assistance and guidance with their tasks. Teachers also saw students' lack of motivation to participate in the virtual forums and chats as something problematic.According to the authors, teachers valued those aspects of blended learning which were related to students' autonomous learning, while those aspects of blended learning which focused on the input of the teacher were regarded as questionable. They provide two explanations for this:

On the one hand, these findings may show that while acclaiming the factor of independence and autonomy in blended learning, the teachers still prefer the traditional face-to-face interaction for a teacher-learner contact. On the other hand, the teachers might feel [a] lack of competence and experience in e-communication and therefore be rather unsure about the usefulness of this form of contact with their students (p.125).

As can be noticed, research on the implementation of blended models has yielded different results. Some researchers contend that language learning is enhanced through the exposure learners have to the blended learning model, while others indicate that there is not significant improvement in comparison with more conventional (F2F) means of instruction. In terms of levels of satisfaction, different opinions have also been reported. One of the most significant aspects noted in the studies, however, despite their variance in methodological grounds and results, is the need for students and teachers to learn to adapt to studying/teaching online. Although BL implies the combination of both faceto-face and online instruction, the implementation of the online component is the one which seems to cause more difficulties for teachers and learners in that it implies a change in roles and the acquisition of new skills and knowledge.

As Bañados (2006) states, teachers' and students' roles change considerably as a result of their participation in a blended program. Students need to learn to be responsible for their own learning process and teachers ought to take on 
roles as material designers, producers of media resources, managers of the learning environment, and online tutors. As a result of all these complex phenomena, "students [just as teachers] may favor one of the delivery modes to the detriment of the other" (Sharma, 2010, p.457), or may even resist or oppose the whole blended experience.

In the case of teachers, being online tutors implies a quantitative increase in the number of hours dedicated to learners and to the learning of new skills, but most importantly, a change in identity as there are new roles and pedagogical perspectives that have to be taken into consideration (Comas-Quinn, 2011). Due to all these implications, it is clear that online learning and teaching challenge not only the conventional roles of students, but also of those of teachers and materials. Also, the pre-established conceptions and expectations about what, when and how to teach/learn are greatly modified. As observed by Bijeikien, Rašinskien and Zutkien (2011), "it is not only the quest of what ICT to blend in and how much of it would allow for the best results, but also [a] wish to keep pace with the technology that burden language teachers nowadays" (p.123).

\section{Why is it Sometimes Difficult to Blend?}

Compton (2009), in agreement with Hampel and Stickler (2005), states that the online context of language learning has generated the need for new teaching approaches and teaching skills different from those used in teaching face-toface language courses. Teachers not only need different skills from those experienced in the traditional face-to-face language classroom, but also different skills from online teachers of other subjects. According to Compton, the assumption that a teacher who is good at teaching in a faceto-face class can easily move to this new medium is a myth. As contended by Easton (2003, cited by Compton, 2009) the online instructor needs to have a paradigm shift in perceptions of instructional time and space, virtual management techniques, and ways of engaging students through virtual communications (p.75).

As argued by Bennett and Marsh (2002, cited by Compton, 2009), there are two important pieces of knowledge that go beyond the technical level. Teachers who teach online need to: "(a) identify the significant difference and similarities between face-to-face and online learning and teaching contexts, and (b) identify strategies and techniques to facilitate online learning and help students exploit the advantages in relation to both independent and collaborative learning" (p. 76). Besides that, teachers need to develop community building skills and promote socialization and active participation. Teachers who take part in blended programs usually need to be face-to-face instructors as well as online tutors; however, though they might effectively cope with the face-to-face model, they might not necessarily know how put into action the online component of the course. After all, "online language teachers cannot be expected to become effective based on training meant for face-to- face classrooms when these two environments involve different skills and responsibilities" (Compton, 2009, p. 96).

Hampel and Stickler (2008) note that online classroom management is also different from a face-to-face classroom; turn-taking, for instance, needs to be organized very differently and teachers have to support learners in coping with a differently structured discourse. Online tutors therefore need to develop different skills:

Online tutors have to not only help students to develop their technical skills in using the virtual environment but also constantly be aware of benefits and challenges of online learning. They have to be familiar with the technology and know about the implications that the medium 
has in the context of teaching a language. They have to rely on their expertise as language teachers as well as knowing how to use virtual environments in the context of useful approaches to language learning... They also need to develop the skill of creating online communities or social entities for language learning. (p.315-316)

According to Hampel and Stickler, online pedagogy is not something completely new and mysterious for language teachers; in fact, some of the problems online teachers face are similar to those encountered in face-to-face classes. Nonetheless, some of these problems need different solutions and it is therefore necessary to consider the training needs of online language teachers in particular. In a similar vein, MorteraGutierrez (2006) contends that success is not just having traditional F2F instructors in place and providing teachers with computer communication technology, expecting they will develop acceptable skills, but "it is training them with pedagogical and didactical tools, and teaching them how to handle blended learning courses" (p. 335).

Nonetheless, despite the need for training and the development of new skills and a sound online pedagogy, there are other aspects that also have a bearing on teachers' effective uptake of technology-mediated practices. Some of the studies that have been conducted in the mainstream classroom and which are related to more conventional uses of technology provide us with important insights. In 1999, Ertmer (cited in Ertmer, Ottenbreit-Leftwich, Sadik, Sendurur $\mathcal{E}$ Sendurur, 2012), established two types of barriers that impacted teachers' uses of technology in the classroom. First-order barriers, defined as those that were external to the teacher and that included resources, training, and support, and secondorder barriers, which were internal to the teacher and included teachers' confidence, beliefs about teaching and learning, as well as the perceived value of technology to the teaching/learning process. "Although first-order barriers had been documented as posing significant obstacles to achieving technology integration, underlying second-order barriers were thought to pose the greater challenge" (Ertmer et al. p.423).

The studies that will be described next examine some of those first and second-order barriers. Demetriadis et al. (2003), in the context of a training project in secondary schools in Greece, investigated teachers' attitudes towards the incorporation of ICT modes into the classroom. Findings suggest that teachers are willing to explore and implement ICT modes to the extent that these are compatible with established methodologies and curriculum and with their own views about what is meaningful and effective for their students. In a similar vein, Hughes (2005), who reports the pedagogical experiences of four language arts teachers, states that the power to develop innovative technology-supported pedagogy lies in the teacher's interpretation of the value of technology for supporting instruction and learning in the classroom.

Interestingly, data from Hughes' study reveal not only open and communicative modes of ICTbased teaching, but also the assimilation of ICT tools into traditional teacher-centered methods. In reference to this phenomenon, Hughes maintains that technology in education has the potential to innovate but also to maintain the status quo. Teachers might employ technology "in ways that are least distant from their practice" to sustain rather than innovate current pedagogical practice. As Dat (2002, cited in Tomlinson, 2005) observes, teachers. when experimenting with new methodologies, normally teach according to their own sets of standards and beliefs. If some of these beliefs lead to the conclusion that students will be unable to profit from new technology, teachers 
might accept the status quo and prevent change from happening.

This acceptance of the status quo does not necessarily imply that teachers are unable to change; on the contrary, this might be explained as a result of the social roles that are assigned to teachers. Demetriadis et al. (2003), in agreement with Billet (2001), claim that "the specific socially imposed requirements of a particular [job] influence the way that the abstracted knowledge of the occupation is manifested in practice" (p.31). That is, teachers' "situational nature of expertise", where there might be a strong emphasis on assessment, may become an impediment to the following of innovative learning methods. The fact that teachers feel compelled to help students pass examinations might discourage their use of ICT modes in a more transformative way.

Such constraints experienced by Demetriadis et al. are not foreign to what many teachers and students experience worldwide. Issues of assessment, specifically official testing, are also considered by Sugar, Crawley and Fine (2004) in their study of teachers' beliefs about technology adoption. In their analysis of the beliefs of six high school teachers, they established that the use of technology of some of the participants was limited by the type of knowledge and skills that official examinations required. Their use of ICT modes was thus restricted to the practices or activities that seemed to facilitate testing training; that is, that which helped students pass official examinations. Moreover, as the authors suggest, there are not only personal factors influencing teachers' decisions to adopt a new technology, such as the benefits they perceive technology will bring to students, but also normative factors like the support or approval it can receive from other members (parents, administrators, principals, etc) and contextual elements like training, time, budget, standardized testing, and learner/learning differences.
In a similar vein, McGrail (2005) and Finley and Hartman (2004), examining teachers' attitudes and experiences of ICT integration in high school and tertiary contexts respectively, indicate that some teachers may not always clearly see whether ICT use addresses educational objectives, and as a result, they may feel it is no different from other methods that deal with the same content. Teachers in McGrail's study, for instance, "resisted pressure from the administration to use technology in their classrooms when they felt it was not as effective as other alternatives available to them" (p.18). They were aware of the fact that technology was changing the concept of English and literacy (their subject area), yet they resisted ICT use every time they felt it was not translatable into practice.

Despite being conducted from different methodological approaches, the above studies concur on one fact: Teachers will not feel willing to implement ICT or CALL tools if they feel there is "a lack of a clearly articulated vision for appropriate technology use" (Finley \& Hartman, 2004). Similarly, giving teachers and students access to online facilities will not necessarily result in them effectively using these tools, since they might not personally experience the benefits of these resources and they might, conversely, feel a sense of marginalization as their traditional information sources are no longer being used (Bach, Haynes \& Smith, 2006).

Demetriadis et al. (2003) maintain that in order to understand teachers' behaviors and the reasons why they may feel enthusiastic and reluctant about the use of ICT modes, it is necessary to bear in mind various conditions. Teachers need to feel that: a) ICT use enhances the quality of their teaching as well as their professional image (effectiveness); b) ICT use will not interfere with the established course of action or with curricular goals they desire to 
achieve (avoidance of disturbances); and c) they are confident with the use of the tools (feeling of control).

Whenever any of these conditions falters, school and ICT cultures are in tension and a negotiation process between cultures needs to be initiated. It is also of importance to consider, as Hughes (2005) illustrates, that teachers' interpretation of the value of ICT is also mediated by their prior learning experiences with technology. Such past experience and accumulated knowledge, as contended also by Comas-Quinn (2011), play a crucial role in their learning process and impact how they use technology in their practice.

According to Borg (2003), social, psychological and environmental realities of the school and classroom, which include parents, principals' requirements, the school, society, curriculum mandates, classroom and school layout, school policies, colleagues, standardized testing, and the availability of resources are factors that "may hinder language teachers' ability to adopt practices which reflect their beliefs" (p.95).

As evidenced above, teachers are influenced by a wide variety of contextual and personal aspects that affect their perception about technology and in turn the kind of learning opportunities they provide their students with. These external and internal factors will often come to shape teachers' experiences with technology whether they are taking part in blended courses or in other programs where technology is used in more conventional ways. Some of the studies on blended learning previously described, although suggesting important practical and pedagogical implications for language learning and teaching, do not take into consideration the various personal and professional factors affecting the transition that teachers experience when moving from fully face-to-face environments to blended environments where a high online learning component is often present. It is therefore important for researchers to focus their attention not only on the observable and measurable (language performance and levels of satisfaction) implications of hybrid innovations, but also on the internal and external realities that are part of teachers' lives, since they also have a bearing on how BL is interpreted and put into action.

The more technology influences our lives, the greater the feeling that it is part of the pedagogical structuring process of educational institutions, and "whether teachers accept technology or not, academic institutions [will continue] mandating integration of technology into academic programs" (White, 2006, p. 18). As a consequence, as stressed by Hamper and Stickler (2008), conducting research into teachers' or tutors' attitudes and teaching styles, their use of the online media and their awareness of the different interaction patterns of online and face-to- face communication, among other aspects, would benefit the development of best practice in online, and I would venture to say, blended learning tuition.

Concluding Thoughts: In Search for Alternative Understandings

"In the realms of BL there is still a lot of undiscovered territory to be explored and mapped out. BL will play an important role in the future of CALL and its implementations in everyday teaching practice. Therefore, we need to learn more about its workings" (Neumeier, 2005, p176).

As Hong and Samimy claim (2010), despite the popularity of BL, the substantial question about whether L2 teachers and learners benefit from the intended efficacy of BL has not fully been confirmed. It still needs to be shown that it lives up to the expectations of designers, teachers, 
students and institutions, and that there is a real improvement not only on language learning but on language pedagogy. As White (2006) notes, some teachers may allow the available technological tools to direct or shape their instructional choices, rather than technology being required to serve pedagogy. This is so as online technologies have improved in quality and power, while the same cannot be said about online pedagogies: "As innovations in technology and practice have clearly outstripped theory development, the use of technology in learning environments has tended to be technology- rather than theory- led" (p.250). Hence, research supported by different theoretical and methodological perspectives is required to better characterize the ways in which teachers and other educational actors come to terms with new pedagogical practices.

Additionally, as also stated by White, there are several questions that both distance and blended learning education research has not yet responded and that can be resolved by relying on the knowledge of different disciplines as well as on second language acquisition theories. Questions such as how learning is socially constructed in virtual learning environments, what personal, psychological or sociocultural factors inhibit language learning and teaching, what types of online pedagogies emerge in blended environments, and to what extent teachers have adopted strong CALL principles reflect some of the issues that should be considered by language researchers in future studies.

In this article, I have reviewed some of the theory and research related to blended learning and ICT use from the perspective of the teacher in both language and mainstream contexts. This review, though far from comprehensive, is an attempt to point out some of the issues that seem to be absent in discussions on blended learning and that have been considered by researchers, whose work originates in fields such as education, psychology and applied linguistics. By identifying some of the aspects that remain to be revisited in the literature on blended language learning, novice researchers might be able to take new research venues that allow us to construct alternative interpretations in terms of not only blended and online learning, but also the use of ICT in general.

\section{References}

Bach, S., Haynes, P., \& Smith, J. L. (2006). Online learning and teaching in higher education. Buckingham, UK: Open University Press.

Banados, E. (2006). A blended-learning pedagogical model for teaching and learning EFL successfully through an online interactive multimedia environment. CALICO Journal, 23(3), 533-550.

Bijeikien $\square$ V., Rašinskien $\square$ S., \& Zutkien , L. (2011). Teachers' attitudes towards the use of blended learning in general English classroom. Studies About Languages, 18, 122-127.

Blake, R. J. (2008). Brave new digital classroom: Technology and foreign language learning. Washington, D.C.: Georgetown University Press.

Borg, S. (2003). Teacher cognition in language teaching: A review of research in what language teachers think, know, believe, and do. Language Teaching, 36, 81-109.

Comas-Quinn, A. (2011). Learning to teach online or learning to become an online teacher: An exploration of teachers' experiences in a blended learning course. ReCALL, 23(3), 218-232.

Compton, L. (2009). Preparing language teachers to teach language online: A look at skills, roles, and responsibilities. Computer Assisted Language Learning, 22(1),73-99.

Demetriadis, S., Barbas, A., Molohides, A., Palaigeorgiou, G., Psillos, D., Vlahavas, I., ... A. Pombortsis, A. (2003). Cultures in negotiation: Teachers' acceptance/resistance attitudes considering the infusion of technology into schools. Computers and Education, 41, 19-37.

Ertmer, P., Ottenbreit-Leftwich, A., Sadik, O., Sendurur, E., \& Sendurur, P. (2012). Teacher beliefs and technology integration practices: A critical relationship. Computers \& Education, 59, 423-435. 
Eseryel, D. (2002). A Framework for Evaluation and Selection of E-Learning Solutions. In M. Driscoll \& T. Reeves (Eds.), Proceedings of World Conference on E-Learning in Corporate, Government, Healthcare, and Higher Education 2002 (pp. 275-282). Chesapeake, VA: AACE.

Finley, L., \& Hartman, D. (2004). Institutional change and resistance: A teacher preparatory faculty and technology integration. Journal of Technology and Teacher Education, 12(3), 319-327.

Fullan, M. (Ed.). (1997). The challenge of school change: A collection of articles. New York: Hawker Brownlow.

Grgurovi , M. (2010). Technology-enhanced blended language learning in an ESL class: A description of a model and an application of the diffusion of Innovations theory. Unpublished doctoral dissertation, lowa State University.

Grgurovi $\square$ M. (2011). Blended learning in an ESL Class: A case study. CALICO Journal, 29 (1),100-117.

Hong, K., \& Samimy, K., (2010). The influence of L2 teachers' use of CALL modes on language learners' reactions to blended learning. CALICO Journal, 27(2), 328-348.

Hughes, J. (2005). The role of teacher knowledge and learning experience in forming technologyintegrated pedagogy. Journal of Technology and Teacher Education, 13(2), 277-289.

Jonassen, D. H., Howland, J., Moore, J., \& Marra, R. M. (2003). Learning to solve problems with technology: A constructivist perspective ( $2^{\text {nd }}$ ed.). Upper Saddle River, NJ: Merrill Prentice Hall.

Kelly, A. V. (2009). The curriculum: Theory and practice (6th ed.). London: SAGE.

Hampel, R., \& Stickler, U. (2005). New skills for new classrooms: Training tutors to teach languages online. Computer Assisted Language Learning, 18(4), 311-326.

Laurillard, D. (2002). Rethinking University Teaching. A conversational framework for the effective use of learning technologies (2nd ed.). London: Routledge.

Lamie, J. (2005). Evaluating change in English language teaching. New York: Palgrave Macmillan.

Lim, D., Morris, M., \& Kupritz, V. (2007). Online vs. blended learning: Differences in instructional outcomes and learner satisfaction. Retrieved September, 2012 from: http://sloanconsortium.org/ jaln/v11n2/online-vs-blended-learning-differencesinstructional-outcomes-and-learner-satisfaction
Lo Bianco, J. (2010). Language policy and planning. In. N.H. Hornberger \& S.L. McKay (Eds.), Sociolinguistics and language education (pp. 143-174). Bristol, UK: Multilingual Matters.

MacDonald, J. (2008). Blended learning and online tutoring: A good practice guide. Aldershot, UK: Gower.

McGrail, E. (2005). Teachers, technology and change: English teachers' perspectives. Journal of Technology and Teacher Education, 13(1), 5-14.

Means, B.(2008). Technology's role in curriculum and instruction. In F. M. Connelly, M. F. He, \& J. Phillion (Eds.), The SAGE Handbook of Curriculum and Instruction (pp. 123-145). Thousand Oaks, CA: SAGE. doi: 10.4135/978-1-41297-657-2.n6.

Mortera-Gutierrez, F. (2006). Faculty best practices using blended learning in e-learning and face-toface instruction. International Journal on E-learning, 5(3), 313-337.

Motteram, G. (2006). Blended education and the transformation of teachers: a long-term case study in postgraduate UK education. British Journal of Educational Technology, 37(1), 17-30.

Murday, K., Ushida, E., \& Chenoweth, N. A. (2006). Student learning in hybrid French and Spanish courses: An overview of language online. CALICO, 24(1), 115-145.

Murday, K., Ushida, E., \& Chenoweth, N. A. (2008). Learners' and teachers' perspectives on language online. Computer Assisted Language Learning, 21(2), 125-142.

Neumeier, P. (2005). A closer look at blended learning: Parameters for designing a blended learning environment for language teaching and learning. ReCALL 17(2), 163-178.

Osguthorpe, R.T., \& Graham, C.R. (2003). Blended learning environment: Definitions and directions. The Quarterly Review of Distance Education, 4(3), 227-233.

Picciano, A. (2009). Blending with purpose: The multimodal model. Journal of Asynchronous Learning Networks, 13(1), 7-18.

Sharma, P. (2010). Blended learning. ELT Journal, 64(4), 456-458.

Sharma, P., \& Barret, B. (2007). Blended learning: Using technology in a beyond the language classroom. Thailand: Macmillan Publishers Limited. 
Shelly, M., White, C., Baumann, U., \& Murphy, L. (2006). 'It's a unique role!' Perspectives on tutor attributes and expertise in distance language teaching. International Review of Research in Open and Distance Learning, 3(2), 1-14.

Sugar, W., Crawley, F., \& Fine, B. (2004). Examining teachers' decisions to adopt new technology. Educational Technology and Society, 7(4), 201-213.

Ricento, T., \& Hornberger. N. (1996). Unpeeling the onion: Language planning and policy and the ELT professional. TESOL Quarterly, 30(3), 401-427.
Tayebinik,M., \& Puteh, M. (2012). Blended learning or e-learning? IMACST, 3(1), 103-110.

Tomlinson, B. (2005). English as a foreign language: Matching procedures to the contexts of learning. In E. Hinkel (Ed.), Handbook of research in second language teaching and learning (pp.137-154). Mahwah, NJ: Lawence Erlbaum Associates.

Westbrook, K. (2008). The beginning of the end for blended learning? IATEFL CALL Review. Summer 2008: 12-15.

White, C. (2006). Distance learning of foreign languages. Language Teaching, 39, 247-264.

THE AUTHOR

Jenny Alexandra Mendieta Aguilar holds an undergraduate degree in TEFL and master's degree in Applied Linguistics from Universidad Distrital Francisco Jose de Caldas. She is currently undertaking a PhD program in Language Teaching at the University of Auckland, New Zealand and is working for the Masters Program In English Language Teaching For Self - Directed Learning at Universidad de La Sabana. Her main interests are curriculum design, self-directed learning, blended learning, and narrative approaches to educational research. 